\title{
A biblical approach to the reduction of child poverty in Anambra state, Nigeria
}

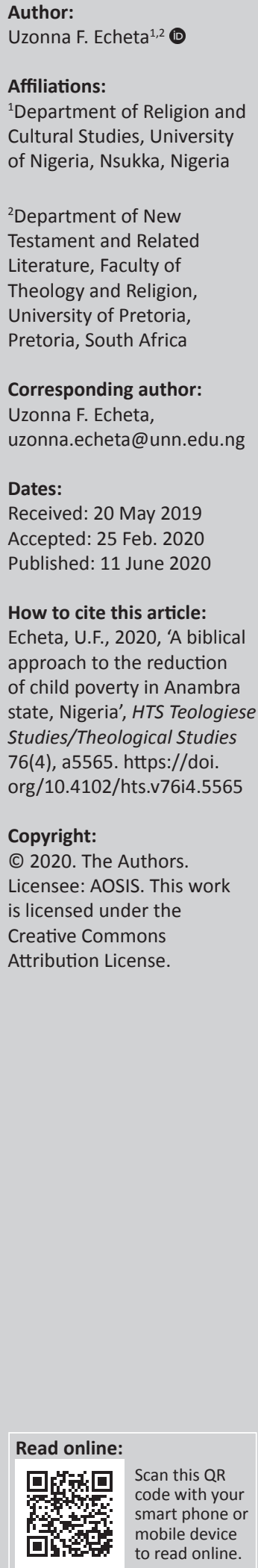

Child poverty reduction is one of the most important and urgent tasks that requires attention in most regions of the world, nations and Anambra state specifically. The population of impoverished children is progressively increasing in Nigeria because of economic recession and poor security situations that lead to displacement and death of their parents. Although children constitute half of the entire population, commensurate attention is not given to them to match the dimensions of poverty they face. This study argued that child poverty is multidimensional, evidenced in lack of safe drinking water, adequate nutrition, shelter, decent sanitation, medical advice or health services (immunisations) and education, to mention a few. The article highlighted the laudable efforts of the United Nations International Children's Emergency Fund (UNICEF) and Anambra government and maintained that multiple strategies can help in solving this problem. To complement these efforts, the enforcement of biblical policies or principles about children's rights would in no small measure reduce child poverty. It was concluded that a proper repositioning of children would be matched with implementation of biblical strategies. Biblical intervention could help children socially, mentally and psychologically and in their general well-being. Biblical principles would erase wrong socio-cultural notions about children.

Keywords: Child poverty; Biblical intervention; Child deprivation; Child abuse; Child labour; Anambra state.

\section{Introduction}

Child poverty occurs when children are deprived of certain basic needs which they require for comfort and survival. Merriam-Webster Dictionary (n.d.) defines a child as an unborn or recently born person, a young person between infancy and youth and who by law is not yet of age. For Olusegun and Idowu (2016:2), Section 277 of the Child's Rights Act of 2003 defines a child as 'a person who has not attained the age of eighteen years'. To strike a balance, a child in the context of this article includes anyone between the age of 0 and 18 years. Data from 89 countries, representing just over $84 \%$ of the developing world's population, show that in 2013 almost 385 million $(\mathrm{m})$ children were living in extremely poor households and the younger children are worse off. Latest data of Multidimensional Child Poverty Index state that $83 \%$ of all multidimensional poor live in sub-Saharan Africa and South Asia (United Nations Development Programme \& Oxford Poverty and Human Development Initiative [UNDP \& OPHI] 2018). Even though multidimensional poverty is found in all developing countries, it is quite acute and pronounced in sub-Saharan Africa.

A joint statement by partners united in the fight against child poverty (UNICEF 2015:1) states that since the turn of the millennium when the world leaders adopted the Millennium Development Goals (MDGs), there has been unprecedented progress in alleviating and improving the living standard of millions of children and families.

However, many of these disadvantaged children are left behind. Stewart and Okubo (2017:40) add that the task of reducing child poverty is an urgent one, but children have received relatively little attention.

From the report prepared by Bello (2015:10) about the state of children globally, and across states in Nigeria, the MDGs helped in improving children's well-being. For instance, appreciable progress has been made in meeting MDG's target of primary school enrolment, and extreme poverty in developing countries has declined from about $47 \%$ in 1990 to $14 \%$ in 2015. Bello further

Note: Special Collection entitled Africa Platform for NT Scholars, sub-edited by Ernest van Eck (UP) 
notes that even though substantial progress has been made globally, there are variations across regions, countries and within countries. Nigeria as a country has not met the target of eradicating hunger and poverty.

The Child Development Index (CDI) (the first-ever global multidimensional tool) helps to monitor how individual countries are performing in relation to the well-being of their children. Child Development Index is based on an aggregate of three indicators that contribute to children's well-being and development - health, education and nutrition.

The CDI scale is rated from 0 to 100 , with a score of zero as the best indicator because the score gives an indication of the level of deprivation (UNICEF 2012:vi).

As can be seen in Table 1, developed countries have the lowest child deprivation level with a score of 2.1, meaning that the incidence of child poverty is low whereas subSaharan Africa has the highest score of 34.5. Even though Africa appears to have a high level of poverty, some African countries have made good progress in reducing child poverty. Rufai et al. (2016:40) observed that Nigeria in particular contributes significantly to the high poverty levels of Africa as $69 \%$ of its populace (about $163 \mathrm{~m}$ people) lives in poverty.

The level of child poverty has worsened in the state because of the generally worsening economic, ecological and social situations in Anambra and other neighbouring states. For instance, the 2012 national flood severely affected several communities in Anambra state, submerging up to 10000 homes and displacing about 125000 people (Ezeokoli, Okoye \& Ugochukwu 2015:130). Similarly, several farmers-herdsmen clashes have resulted in the death of many youths and farmers, who were most likely parents, thus resulting in the poverty of children left behind (Okeke, Nnamani \& Dibia 2018:108).

Speaking from a biblical perspective, Evans (1915:2426-2427) identifies poor harvest (Neh 5:1-3), enemy encroachment on the land and the oppression of people by their rulers as some of the causes of poverty.

Although efforts have been made through both policy enactments in the state and Sustainable Development Goals (SDG) to eradicate hunger by 2030, Stewart and Okubo (2017:3) still maintain that child poverty persists. As it is, a diversification of strategies or a multidimensional approach would be a better way to tackle the problem.

TABLE 1: The Child Development Index of countries.

\begin{tabular}{lcl}
\hline Countries & Scale & Deprivation level \\
\hline Developed countries & 2.1 & Lowest level \\
Latin America & 6.8 & Second to lowest \\
East Asia & 8.5 & Next \\
Central East Europe & 9.2 & Next \\
Middle East/North Africa & 11.2 & Next \\
Africa & 34.5 & Highest level \\
\hline
\end{tabular}

Source: UNICEF, 2012, Save the children: The child development index-Holding governments to account for children's wellbeing, viewed 31 December 2019, from https://unicef.org/ socialpolicy/files/child-development-index.pdf.
In line with this proposition of multidimensional strategies, this study proposes a biblical approach as an ideal complement to other strategies with its principles and instructive appeal to conscience and reasoning. To achieve this aim, the article reviews related literature on child poverty in Anambra state (its brief history and child poverty level); discusses biblical intervention towards reducing child poverty and finally makes recommendations.

\section{Literature review}

Various contributions on child poverty have shown a link between child poverty, child labour and child abuse. In fact, all of them are dimensions through which children experience child poverty. A few works are here reviewed in order to show how society views this phenomenon. Akhilomen (2006:236) simply states that child abuse is linked to a lack of social support, poverty and poor housing.

Stewart and Okubo (2017:19) describe child poverty as a global affair, and although numerous efforts have been made to end this problem, children still experience poverty. The authors give a lucid picture of devastating and long-term consequences of this cankerworm both on children and entire society. For them, reducing child poverty should be a national top priority for the following reasons: Child poverty matters to children and is a violation of their rights; its devastating effects last for entire life; the effects of poverty are felt more by children than adults; and even though ending child poverty is an urgent need, comparatively little attention has been given to it than is required.

The last three decades have witnessed good progress in poverty reduction, but considerable attention has not been given to children, even though they make up one-third of the population of developing countries. Effective alleviation of child poverty involves a multidimensional approach which takes child nutrition, education and health into consideration. The effects of undernourishment in children are extremely disastrous because it impacts the growth of children, reduces mental development and eventually results in overall poor health.

Mbah, Mgbemena and Ejike (2016:174) researched on Awka urban area and enumerated the challenges that people living in urban areas face such as lack of good accommodation, electricity, medical welfare occasioned by migration from rural to urban areas and invariably over congestion. Even though these problems were identified to be existent amongst the adults, they are invariably translated to children as child poverty.

Owoaje, Ige and Bamgboye (2011) posit that child labour is a global phenomenon occurring in both developing and developed countries of the world. From their findings:

[A]bout 353 million children are engaged in some form of economic activity globally. Most of these children are in Asia, the Pacific and Africa. The International Labour Organisation reports that about 120 million children are fully working in 
developing countries, whilst 250 million are working and schooling concurrently. Most of these children are employed for long hours and paid low wages. Currently, in most African countries the prevalence of child labour ranges from $20 \%$ to $54 \%$. Poverty is the greatest single force which creates the flow of children into the workplace. Poorer households indulge in child labour more than those that are considerably well off. (p. 12)

Okeke (2015) remarks that the number of child street hawkers has been on a progressive increase. He further notes that the International Labour Organisation estimates that in Nigeria, $14 \mathrm{~m}$ children aged between 4 and 14 years are involved in a form of economic activity. The short-term effect of this is discomfort for the child, but it translates into hazardous child labour, child abuse and even child trafficking and death in the long run. Exposing children to such untold hardship is the highest manifestation of poverty a child can experience in life.

The World Health Organization (WHO 2016) opines that child labour is a global problem that occurs in children aged younger than 18 years and is deeply rooted in the cultural and social practices of the people. This child labour could be invisible and experienced as a psychological and emotional abuse. It could also occur in the form of hitting, punching, kicking, beating and the likes at homes, schools and other institutions. Nwogwugwu et al. (2017:1) lend huge support to the opinion of Owoaje et al. (2011:12) that child labour in Anambra state is simply a survival strategy designed by families. Parents themselves send their children to take up such tasks so as to enable the family to have more money. Unfortunately, this has innumerable negative consequences for a child's development.

Amongst the problems Owoaje et al. (2011) listed that are associated with child labour are physical abuse, fatigue, poor school performance, sexual abuse and youth violence, amongst others. Most of the families that involve their children in child labour have five to nine children; that's why this family size forces them to send their children out to either learn a trade or indulge in menial jobs. Thus, the types of work children do are generally life-threatening and harmful.

Most children admit that they are involved in child labour to help their parents overcome economic hardships.

These types of exercises violate a child's fundamental human rights. Ugochukwu et al. (2012:174) and Nwamaka and Uzonwanne (2017:104) agree that the culprits in this ugly business of child labour are their parents. In all subjects examined, parents were found to be of a low socio-economic status. Child labour is injurious to both child's education and health and ultimately to the society. Onyido and Vareba (2019:43) on the menace of child abuse in Nigeria have generally emphasised that how this phenomenon has been a challenge for child's development and its implication on the nation's sustainable development at large. According to Onyido and Vareba (2019:43), an estimated 15 million
Nigerian children are engaged in one type or the other form of child labour.

Olusegun and Idowu $(2016: 2,16)$ consider the problem from a legal perspective and aver that child abuse is rampant in Nigeria but is largely under-reported. Many laws exist to protect children's rights, but they are ineffective. They referred to the Child's Rights Law 2003, emphasising the problem of non-implementation.

Smith (2003:1312) writes from a biblical perspective, and classifies the poor under a broad umbrella of orphans and widows. For him, the poor are the people of lower social class who need protection from oppression. The word used for the poor has an underlying meaning of 'humble, oppressed or wrongfully oppressed, the fatherless, needy, weak, and dependent' (Job 24:14, 29:12; Ps 10:9; Is 3:14). God has a special consideration for them and instructs that provisions should be made for them to glean in the fields and vineyards (Lv 19:10, 23:22; Dt 24:21) and just treatment given to them. The New Testament reveals that Jesus paid much attention to poor people and preached a message of hope and good news to them (Mt 5:3; Lk 4:18).

In fact, a person's true religious character is measured by his care for orphans and widows as written in James 1:27.

Spender (1996) agrees with Smith's (2003) perspective that from the biblical viewpoint, the poor includes orphans and widows, depending on the context of usage. It is such an important concept that it is discussed in the Old Testament (OT) historical books and the prophets, but the wisdom literature (Job, Psalms, Proverbs and Ecclesiastes) paints a more realistic picture of poverty in the ancient world. Particularly in Job 24, the poor are portrayed as the hungry, thirsty, naked, the sufferer and the oppressed. They are vulnerable and hated even by their own neighbours (Pr 14:20 KJV).

Palmer (2018) has this to say concerning the subject of poverty from the Old Testament's perspective: God considers the welfare of the poor very seriously and issues directives and warnings to the rich and well-to-do to treat the poor well. He opines that poverty in the Old Testament has types and levels. Furthering on the types, he exposes voluntary and non-voluntary poverty. A situation of voluntary poverty arises when a slave who has been freed from the master chooses to remain under the care of the master. Nonvoluntary poverty, which is the most common type, takes place when people are rendered poor by natural disasters, social upheavals, oppressions and wars (https://gobgr.org/ poverty-in-the-old-testament/).

Bitrus (2003:139-140) opines that the Old Testament sets a standard for poverty alleviation and does encourage Christians to develop the right attitude to work. He counters the view of some people that work is to be avoided, or tolerated as a necessary nuisance. Work is seen by some as 
the consequence of the fall (Gen 3). Using the same Old Testament, he argues that man should work in order to subdue the earth as he is mandated in Genesis 1:28 and also to have fulfilment. One excellent contribution made by Bitrus (2003) is that even though Old Testament states that poverty would not be completely eradicated, the same Old Testament provides us a guide for poverty alleviation and Proverbs 31:15-18 is ideal for this analogy. The contribution of Bitrus is balanced and gives no room for laziness for Christians, especially in this era of technology and computerisation when people tend to develop lazy attitudes.

Nwobi and Onwuasoanya (2014:105) state that many Nigerians are not able to afford their basic needs of life, especially the rural women in Anambra state. This becomes a very serious problem for Nigerian society. The tasks which rural women in Anambra state are expected to perform and the skills needed to carry them out vary.

These contributions from both general and the biblical viewpoints have illuminated us on the meanings, levels and dimensions of child poverty. They have also expatiated on the real causes and effects of poverty generally and particularly in Anambra state. Although these contributions are invaluable on this subject, much has not been carried out on how to alleviate child poverty through the implementation of biblical strategies, and that is why this study has focused on it.

\section{Anambra state, brief history and child poverty situation}

Anambra, 'light of the nation' (Ihe Mba) is a state that was created on 27th August 1991. It lies in the south-eastern part of Nigeria with a population of over $4 \mathrm{~m}$ people (Ikezue 2014:163; Okeke et al. 2016:2). It is bounded by Delta state in the west, Imo state in the south, Enugu state in the east and Kogi state to the north. It possesses a history that dates back to the 9th century $\mathrm{AD}$ as revealed by archaeological excavations carried out at Igbo-Ukwu and Ezira (McKenna et al. n.d). The state has Awka as its capital with 21 local government areas. The major urban centres of Anambra are Onitsha, Nnewi and Awka.

The mainstay of the communities is agriculture and trade (Okeke et al. 2016:2). Anambra is a unique state that should be distinguished from all other states because its strength lies in partnership among people which makes its economy strong. According to Willie Obiano - governor of Anambra state - cited in Nwafor (2017), 'Anambra state is the fourth largest economy in Nigeria after Lagos, Abuja and Rivers. It has the lowest poverty rate in Nigeria'. The commercial activities of some towns in Anambra help to boost its economy. Onitsha, for instance, has a fast growing commercial market, one of the largest markets in west Africa which hugely serves to boost the economy of the state and extends to Idemili, Oyi and Anambra East. Nnewi (known as Taiwan of Nigeria), developing both industrially and commercially (Oganiru n.d.), and Ekwuluobia are some of the heavy commercial towns of the state. It has one of the highest population densities in Africa (Okonkwor 2012).

The state is located in core Igboland and the indigenes are known for their strong religious inclinations. There are traditional religious adherents, and other forms of religious practices continue in the state. On the whole, Christian religion overshadows all other religions. Both Ezeonwu (2011:493) and Adamu et al. (2011:6) have observed that 'Christianity is the predominant religion in Anambra state'.

The state puts much of policies in place which help children live an improved lifestyle. The state governor, for instance, has plans to ensure that education becomes the basic right of all children in the state. The state collaborates with the National Agency for the Prohibition of Trafficking in Persons (NAPTIP). This organisation runs sensitisation campaigns against child trafficking and related acts. It emphasises upon the education of women and children. Parents or guardians of the children found hawking in streets during school hours are invited for interrogation. Jannah (2018) states that one in four Nigerian children receive all the recommended vaccines. Children who are never vaccinated are at the greatest risk of contracting diseases such as measles, whooping cough and tetanus, which could be fatal or lead to long-term debilitating effects on survivors. Vaccination helps to prevent diseases such as pneumonia and measles. On World Children's Day, UNICEF Nigeria (2017) informed that poor education, violence against children and terrorism are the biggest concerns for Nigerian children. Children were given the opportunity to relate their own experience with poverty.

According to UNICEF Nigeria (2017):

$[T]$ his forum provides more authentic information and direct report on how children themselves feel about poverty. They expressed concern that the leaders cannot be trusted and this makes them afraid of the future. The UNICEF representative, Mohamed Fall, however, notes that it is our duty to listen to children and treat them fairly. (p. 1)

Various past administrations - Olusegun Obasanjo (National Poverty Eradication and Empowerment Programme [NAPEP]) and Goodluck Jonathan (Subsidy Re-investment and Empowerment Programme [SURE-P]) have tried to reduce poverty, and the federal government under President Buhari has promises of social welfare and expectations are high for its full implementation. Federal government interventions in the fields of children education and nutrition, which are two basic indicators of child poverty, are commendable. Ujumadu (2016) reports that in January 2017, Anambra state was given N67.5 m to cover 10 days feeding of 96489 pupils of primaries $1-3$. The allotted money was directly transferred in the accounts of cooks. Anambra is one of the five states to start this school feeding programme. Children are provided meals during break time, and the meals served are alternated each day.

The state government is expected to complement this by providing meals for pupils of primaries $4-6$. So far, the 
beneficiaries of the feeding programme are urban and semiurban children; rural schools are not yet covered by this programme. Nzemeka (2018) - executive chairman of Anambra State Basic Education Board - informs that the state has not played its role in feeding the other pupils of primaries 4-6 and attributes this to logistic difficulties that hinder new projects.

Nzemeka (2018), however, announced that the state government has plans to introduce mid-day feeding in 16 schools established by the Anambra state governor. Anagwu (2017) observes that Anambra state has fared well generally in education over the years, judging from the performance of children in school certificate, National Examination Council (NECO) and joint admissions and matriculation board examinations.

\section{Discussion}

Child poverty is multidimensional and occurs when a child experiences deprivation of basic needs of life such as good nutrition, education, social welfare, shelter, safe drinking water, medical care and social recognition in the society. Both the Old and New Testaments consider poverty from a multidimensional point of view. The 'poor', in the Bible has a wide range of meanings, including the orphan, the widow, the oppressed, the fatherless (Smith 2003:1312), the hungry, the thirsty, the needy, the weak and the dependent (Job 24:14).

Willie Obiano, the Anambra state governor, is doing appreciably well by investing hugely in poverty alleviation projects because his concentration is on eradicating hunger and improving child education. Apart from extending free feeding in more schools, he has planned to provide more education opportunities to children and halt child hawking on streets. His administration has encouraged individuals to assist in upgrading education in the state.

The Onyebuchi Chris Ifediora Foundation (OCI) is one such Non-Governmental Organisation (NGO) that has immensely contributed in boosting education in Anambra. According to Nzeagwu (2019), in 2018, this organisation granted scholarships to 22 students of senior and junior secondary schools of Omambala area of the state, and in 2019 , it granted scholarships to 35 students of Otuocha.

Another NGO, Augusta Agbasionwe Foundation (ANAF) focuses on providing free meals to primary school children of Awka and some neighbouring towns. This is aimed at providing free meals to indigent students who go to school without food. The meals solve the problem of nutrition and improve children's concentration level and educational performance. Over 3000 pupils of nursery and primary schools have enjoyed free meals in Awka (Udoka School), Nando and Awkuzu (Ujumadu 2016). The school feeding, although a giant stride in tackling child poverty, has concentrated on urban and sub-urban areas only, leaving out children of rural spheres. Onah (2018) writing about the federal government's efforts to alleviate poverty reports that governor Obiano commended the National Cash Transfer Programme (NCTP) of 2016 as a timely step that could help alleviate hunger and sufferings of people now that the cost of living is very high.

Nwafor (2017) reports that Anambra state has the lowest incidence of poverty. Amaefule (2018) reports similarly and states 'that Anambra is rated as one of the lowest poverty states'. Governor Obiano explains the reason why the state fairs well as follows (Nwafor 2017):

$[O]$ ur strength as a state lays [sic] in our partnership with people. Anambra state is the fourth largest economy in Nigeria after Lagos, Abuja and Rivers. Statistics indicate that Anambra state has the lowest poverty rate in Nigeria. (p. 1)

Governor Obiano's comment is not far from truth. However, people actually experience poverty in multiple and simultaneous manner. Poverty rating takes into consideration how people experience deprivation of education, health and living facilities, including lack of sanitation, clean water, and adequate nutrition (OPHI 2018).

Table 2 shows lower MPI values, which mean low poverty level. For example, Lagos state which has an MPI of 0.035 has a lower poverty level than Anambra state with an MPI of 0.05 . In terms of poverty ranking, the higher the numbers, the lower the poverty level. The MPI rating ranked Anambra state at 35 (World Bank 2016:46). Latest global data have revealed that the vast majority - 1.1 billion - of multidimensional poor live in rural areas, where poverty rates at 36\%, are four times higher than urban areas (UNDP \& OPHI 2018).

Even though Anambra state government has put some policies in place to check child poverty, child neglect is pronounced for cultural reasons. This type of poverty causes much pain in children because they are not usually given enough recognition or even hearing in matters where they should be represented. Child neglect happens in virtually all segments of society, even within the Christian bodies

\begin{tabular}{lcc}
\multicolumn{2}{l}{ TABLE 2: Multi-dimensional poverty } & index ranking of some states in Nigeria. \\
\hline States & MPI $\dagger$ & MPI ranking* \\
\hline Lagos & 0.035 & 37 \\
Osun & 0.043 & 36 \\
Anambra & 0.050 & 35 \\
Ekiti & 0.051 & 34 \\
Edo & 0.080 & 33 \\
Imo & 0.083 & 32 \\
Rivers & 0.088 & 31 \\
Abia & 0.088 & 30 \\
Bauchi & 0.583 & 3 \\
Zamfara & 0.605 & 2 \\
Yobe & - & 1 \\
\hline
\end{tabular}

Sources: Oxford Poverty and Human Development Initiative (OPHI), 2017, OPHI country briefing: Nigeria. Data for all, viewed 03 January 2020, from www.dataforall.org/dashboardopiindex Gething and Molini (2015), cited in World Bank, 2016, Poverty reduction in Nigeria in the last decade, Report No. NGA, Poverty Global Practice, Africa Region, World Bank, Washington, DC. $\mathrm{MPI}$, multi-dimensional poverty index.

$\dagger$,Global Multi-dimensional Poverty Index; $\$$, Global Multi-dimensional Poverty Index ranking. 
because of cultural orientation that children are insignificant. In fact, UNICEF representative in Nigeria relates this issue of child neglect and non-recognition as a major concern of Nigerian children. The children complained on World Children's Day that their opinions are not regarded and do not make any impact on society; so they are powerless and disenfranchised. A survey carried out in 2017 found that two out of three children in Nigeria do not think their opinions are heard, and $99 \%$ children believe that the world would be a better place to live in if children are heard by world leaders (UNICEF 2017).

Indeed, children experience poverty in diverse ways: emotionally, socially (through social discrimination amongst their peers), financially, nutritionally as well as health-wise. There could be other forms of poverty to which children may be exposed if they are not heard.

Child poverty should be addressed urgently because it affects both the destiny of a child and that of the society negatively.

\section{Biblical intervention towards reduction of child poverty}

The Bible is a versatile and contemporaneous book. It is economically, socially, psychologically and spiritually ideal for all human conditions. It becomes imperative in this study to explain further and in greater detail the meaning and the concept of poverty from the biblical perspective before elucidating how biblical principles could be implemented for the effective reduction of child poverty.

Poverty is a very important concept in biblical theology and that is why it has been used as many as 204 times in the Old Testament and 35 times in the New Testament. Poverty has its root in the Hebrew word anav or aniy, meaning 'poor, afflicted, depressed in mind or circumstances, lowly, needy, humble and meek' (Strong 1990:108). In Greek, poor or ptochos means a beggar or a pauper (strictly denoting absolute or public mendicancy, although also used in a qualified or relative sense).

In the Old Testament, the concept of poverty is that poverty cannot be completely eradicated from the society. This notion finds expression in the book of Deuteronomy (15 [KJV]), which states that:

$[T]$ he poor shall never cease out of the land, therefore I command thee saying, thou shalt open thine hand wide unto thy brother, to thy poor and to thy needy in thy land. (v. 11)

In the Old Testament, God gives tremendous hope to the poor by promising to take care of them, make them rich $(1 \mathrm{Sm}$ $2: 2,8)$ and deliver them from those who are too strong for them (Ps 35:10).

God's strong attachment to the poor is glaringly shown all through the Old and New Testaments, in the historical books, wisdom literature and the prophets, and in James 1:27: 'Pure and undefiled religious practice is one that takes care of the orphans and widows... and such pleases God'. God satisfies the longing of the hungry or poor with good things but sends the rich away empty (Lk 1:35). God frowns at any form of maltreatment of the poor (Ex 3:7-8; Dt 26:6-9).

His commitment to defend their cause manifests in his various instructions to the rich to treat them fairly, pay their wages and provide leftovers in the vineyards for them to glean (Lv 19:10; 23:23).

Anyone who cares for the poor renders service to God and attracts blessings in abundance and divine security for himself. This is clearly shown in Psalm 41 (NIV), which states:

$[B]$ lessed is he who has regard for the weak; the Lord delivers him in times of trouble. The Lord will protect him and preserve his life; he will bless him in the land and not surrender him to the desire of his foes. The Lord will sustain him on his sick bed ... (vv. 1-3)

On the contrary, those who maltreat the poor would face severe judgement and punishment (Am 4:2).

Mark 10 (NIV) reports a case of child poverty exemplified in child neglect, social rejection and the intervention of Jesus to the poverty experienced by children:

People were bringing little children to Jesus to have him touch them, but the disciples rebuked them. When Jesus saw this, he was indignant. He said to them, Let the little children come to me, and do not hinder them; for the kingdom of God belongs to such as these. (vv. 13-14)

- Biblical principles on children's human rights: Significantly, the Bible, more than any other book, promotes the rights of children and enjoins adults to accord children the right to recognition in the society. Based on the principle of recognition, that Jesus frowned at his disciples who refused to accord children their right to be blessed by him (Mk 10:13-14). He eventually took the children and blessed them to demonstrate the fact that they have full right of participation and recognition similar to adults. Children are so important that if anyone deceives them, thus causing them pain, the person would face very severe punishment (Mt 18:6). Human rights demand that one is recognised as part and parcel of the system and has rights of expression and participation. On the contrary, this is denied to children because they are not considered as full human beings. Denying children the right of expression is a core aspect of child poverty that was voiced by children on World Children's Day in Anambra state. Children were pained for they were not given the chance to express themselves and no one had time to listen to them. Societal recognition is one of the deprivations that children suffer, but the Bible has a stand against it. The Bible makes adequate provisions for children in terms of their societal recognition.

- Biblical teaching on child education: Deuteronomy 6:6-9 is very emphatic on the issue of child education, whether formal or informal. It commands parents to educate their children at all times not minding the circumstances. This biblical position means that children have a right to be educated, and that 
denial to expose them to good education is incongruous with God's agenda. Therefore, effective education of children which is a major move towards eradicating child poverty has huge biblical support. The Jews were rigid in teaching their children and the home was the child's first contact with education. Jewish mothers were instrumental in teaching their children every aspect of life and religious practice (Nkwoka 1983:59).

- Blessing of children by touching them has biblical origin and reduces poverty drastically: Touching a child for the purpose of blessing and prayers has biblical origin and approval. This biblical principle has enormous psychological implications. In fact, Cari (2018:2-3) observes that 'affectionate touch in particular is a necessary ingredient for humans to thrive and when we go without it over an extended period of time, the physical, mental and emotional consequences can be severe and long lasting'. The Jews observed blessing of their children seriously and blessings in many cases were given by fathers but mothers also bless in some cases. Culturally, blessing children by placing hands on them was highly valued in the community. Hebrew mothers, for instance, were accustomed to seek blessings for their children from synagogue heads, prophets and rabbis. Jesus exemplified the importance of imposition of hands on children when he took them in his arms, touched them and blessed them. In fact, Jesus rebuked his disciples for refusing parents from bringing children to him (Mk 10:13-14). Touching a child positively by embracing, caressing and curdling forms a connection between the person who touches and the child. It communicates a sense of security, love, well-being and comfort for the child (Bryant 2017). When a child is touched, he develops trust and relaxation and also a feeling of security according to Chillot (2013:57). In fact, Jones (2017) opines that touch in infancy is important for healthy brain development. This is demonstrated in a research conducted at the National children's hospital in Columbus $\mathrm{OH}$, where researchers fitted heads of 125 babies with electrodes. They went ahead to record their brain activity whilst their skin was touched lightly. Therefore, not touching infants and children has devastating effects on them and could lead to violence and increased disease experience and poor brain development. That is why Jesus objected to this form of child poverty. Colleen Kraft, president of the American Academy of Pediatrics, has described implementation of President Trump's non-touch rule for immigrants' children as government-sanctioned child abuse (Cari 2018).

- Introduction of biblical nutrition to children: Ogbebo cited in Rufai et al. (2016:40) was correct when he stated that poor nutritional knowledge amongst parents leads to malnutrition, rather than poverty. Nutrition is a core determinant of poverty and that is why it is one of the tools used to evaluate poverty rate in Anambra state. A good deal of efforts are made to produce sufficient food and eradicate hunger amongst children. Food security is one dimension that is generally accepted as significant in tackling child poverty; however, provision of sufficient food without necessarily providing real/quality nutrition (biblical nutrition) won't stop child poverty in the long run. Ryan (2014) is correct to state that 'access to real food is foundational to climbing out of poverty'.

Ryan (2014) correctly emphasised real food, which is entailed as Biblical nutrition. Biblical nutrition, otherwise known as kosher diet (food that is fit), essentially comprises fruit and vegetables or plant food. This dietary prescription is specified in Genesis 1, where God said:

I give you every seed-bearing plant on the face of the whole earth, and every and every tree that has fruit with seed in it. They will be yours for food. (v. 29)

This plant-based nutrition is exceptional because it contains phytochemicals that prevent the body from contacting chronic diseases and fights free radicals that ravage the human body. Biblical nutrition de-emphasises unnatural or artificial foods and promotes traditional foods that are not over-processed. Biblical nutrition contains lots of vitamins, enzymes and minerals. The intervention of biblical nutrition is needed in the present century because both parents and children make wrong dietary choices, which increase poverty by introducing innumerable diseases in the society. When children are fed properly, their well-being and proper development is guaranteed. For instance, Layade and Adeoye (2014:3) state that 'eating fruits and vegetables (biblical food) appears to keep the brain young and prevent mental decline ...' Vegetables, in general, reduce stress and sharpen the brain. According to Collins (2012), leafy green vegetables, in particular, help slow down mental decline and keep the brain young. Vegetables and fruits such as spinach, celery, broccoli, tomatoes, avocado pea, blueberries, sunflower seeds, green peppers and collards, are all useful in this regard because they counteract negative things and feelings that tend to disrupt brain work. This type of nutrition would ultimately improve the living standard of children and their academic performance.

To prevent absenteeism, tardiness and low performance of children in schools, they should be helped to feed well and include vitamins A, B6, B12 and C, iron, zinc foliate and calcium, which are all supplied by fruits and vegetables - a biblical diet. Iron deficiency in infancy can lead to loss of IQ in later life. Children's intellectual and innovation skills could be enhanced if they start eating biblical food (Dn 1:12-17).

\section{Recommendations and conclusion}

- It is herein suggested that the state government should include planting of fruits and vegetables in its food production agenda to make products sufficient, accessible and affordable.

- Pupils should be encouraged to indulge in farming as part of their practicals in agriculture.

- Sensitisation and promotion of fruit and vegetable dieting has become an urgent task to sustain health and secure the future of younger generation.

- Touching our children in infancy is very important for reducing child poverty, so parents should do that more often.

- Recognition of children's interests at home, school and society is a priority as taught by biblical principles.

- The government should encourage more NGOs in this fight against child poverty. 
This study has examined the current state and welfare of children in Anambra state, highlighting various strategies put in place to alleviate child poverty. Actually, the state has made giant strides in this fight and this is commendable. The areas where the attention of the state should be drawn are the issues of child neglect, child labour and healthy nutrition. If children are recognised as members of the community as exemplified by Jesus, they are likely to be more relevant to society. Blessing children and touching them in infancy has been proved psychologically to help them grow into more useful and productive individuals, and Anambra as well as Nigeria need such people. Biblical principles promote child right, child recognition, child education and implementation of good food rich in vitamins, minerals and enzymes. Ryan (2014) is sure that 'getting out of poverty has to do with a healthy body and healthy mind'. Although he did not say this in very clear and explicit terms, he refers to biblical nutrition. Nutritionists and health experts (Adenegan \& Adeoye 2011; Colbert 2004, 2009; Iwu 1993; Malkmus \& Shockey 2006; Pamplona-Roger 2004) have discovered the health benefits of fruit and vegetables, and some of these have been highlighted in this study. Echeta (2018) elucidates how fruit and vegetables could help people to have healthy body and mind. This study submits that biblical nutrition is a good strategy for prevention of chronic diseases in general. If children are adequately fed with biblical nutrition, their intellectual and innovative skills would be enhanced (Dn 1:12-17). Anambra state, and Nigeria as a whole, need to implement fruit and vegetable diets starting with children because more creative, innovative and productive brains are required that would move the nation forward technologically to compete globally.

Biblical nutrition not only provides food satisfaction but also saves children from diseases and the cost of treatment. Wellstructured nutrition such as biblical nutrition is a propelling force and a child's journey out of poverty. Anambra state and Nigeria need to borrow a leaf from Mark Hyman's words (Ryan 2014), who states the following:

[T] he country [his country] cannot afford the cost of bad food. Because of bad food, our kids are sicker, leading to an achievement gap that limits our capacity to compete in the global market place. (p. 2)

\section{Acknowledgements}

In the course of writing this article, Miss Odinakachukwu Echeta, a lecturer at the University of Lagos, contributed invaluably in providing e-material and rendering computing services. Rev. Dr Chinedu Echeta rendered advisory support.

This is part of the research project "Hermeneutics and Exegesis", directed by Prof. Ernest van Eck, Department of New Testament and Related Literature, Faculty of Theology and Religion, University of Pretoria.

\section{Competing interests}

The author declares that they have no financial or personal relationships which may have inappropriately influenced them in writing this article.

\section{Author's contributions}

U.F.E. is the sole author of this research article.

\section{Ethical considerations}

This article followed all ethical standards for a research without direct contact with human or animal subjects.

\section{Funding information}

This research received no specific grant from any funding agency in the public, commercial or not-for-profit sectors.

\section{Data availability statement}

Data sharing is not applicable to this article as no new data were created or analysed in this study.

\section{Disclaimer}

The views and opinions expressed in this article are those of the author and do not necessarily reflect the official policy or position of any affiliated agency of the author.

\section{References}

Adamu, F., Ajala, O.A., Para-Mallam, J.O. \& Lanre-Abass, B., 2011, Engagements of women's movements with religion: Legal reform in Anambra state, Nigeria, Working paper 60, Unpublished working paper 60, Religions and Development Research Programme, s.n., s.I.

Adenegan, K. \& Adeoye, I.B., 2011, 'Fruit consumption among university of Ibadan students, ARPN Nigeria', Journal of Agricultural and Biological Science 6(6), 18-21. http://www.arpnjournals.com/jabs/research papers/rp_2011/jabs_0611_279. http://w
pdf.

Akhilomen, D., 2006, 'Addressing child abuse in Southern Nigeria: The role of the church', Studies in World Christianity 12(3), 235-248. https://doi.org/10.3366/ swc.2006.0018

Amaefule, E., 2018, 'Poverty more endemic in North West Nigeria - Report', Punch Newspaper, viewed 29 December 2019, from https://punchng.com/povertymore-endemic-in-north-west-nigeria-report.

Anagwu, I., 2017, 'Towards sustainable education in Anambra state', Elombah News, viewed 29 December 2019, from https://elombah.com/towards-sustainableeducation-in-anambra-state-ifeanyi-anagwu/.

Bello, B., 2015, State of the Nigerian children 2015 - Children left behind in Nigeria Report, viewed 29 December 2019, from https://nigeria.savethechildren.net/ sites/nigeria.savethechildren.net/files/library/State $\% 20$ of $\% 20$ Nigerian $\% 20$ children\%20report.pdf.

Bitrus, D., 2003, 'Biblical perspectives on wealth creation, poverty reduction and social peace and justice', Transformation 20(3), 139-143. https://doi.org/10.1177/ 026537880302000304

Bryant, S., 2017, Psychological impact of touch, viewed 29 December 2019, from https://study.com/academy/lesson/psychological-impact-of-touch.html.

Cari, R., 2018, 'The lasting damage of depriving a child of human touch', The Cut viewed 05 January 2020, from https://www.thecut.com/2018/06/the-lastingdamage-of-depriving-a-child-of-human-touch.html.

Chillot, R., 2013, 'The power of touch', Psychology Today, 11 March, p. 57.

Colbert, D., 2004, What you don't know may be killing you, Siloam Press, Lake Mary, FL.

Colbert, D., 2009, Eat this and live, Siloam Press, Lake Mary, FL.

Collins, E., 2012, Keeping the memories alive. How to keep our brains young, viewed 29 December 2019, from http://www.hivehealthmedia.com/keeping-memoriesalive-brains-young

Echeta, U., 2018, Healing wonders of fruit and vegetables (Ezekiel 47:12). Featuring testimonies of healed Nigerians, Rehoboth Publishing, Lagos.

Evans, W., 1915, 'Poverty', in J. Orr (ed.), International standard Bible encyclopedia, vol. 4, pp. 2426-2427, Lakeside Press, Chicago, IL.

Ezeokoli, F.O., Okoye, P.U. \& Ugochukwu, S.C., 2015, 'The upshot of the 2012 flooding on structural components and fabrics of buildings at Ogbaru, Anambra state Nigeria', American Journal of Civil Engineering and Architecture 3(4), 129-136. https://doi.org/10.12691/ajcea-3-4-3

Ezeonwu, M.C., 2011, 'Maternal birth outcomes: Processes and challenges in Anambra state, Nigeria', Health Care for Women International 32(6), 492-514. https://doi. org/10.1080/07399332.2011.555827 
Gething, P. \& Molini V., 2015, 'Developing an updated poverty map for Nigeria', Unpublished working paper, World Bank, Washington, DC.

Ikezue, C.E., 2014, 'Governance and security challenges in Anambra State', Journal of Religion and Human Relations 1(6), 159-170.

Iwu, M., 1993, Handbook of African medicinal plants, CRC Press, London.

Jannah, C., 2018, 'Only 1 in 4 children are vaccinated - UNICEF', Daily Post, viewed 29 December 2019, from https://dailypost.ng/2018/04/23/1-4-nigerian-childrenvaccinated-unicef/.

Jones, H.D., 2017, 'Touch in infancy is important for healthy brain development', in The Conversation, viewed 05 January 2020, from http://theconversation.com/ touch-in-infancy-is-important-for-healthy-brain-development-74864.

Layade, A.A. \& Adeoye, I.B., 2014, 'Fruit and vegetable consumption among students of tertiary institutions in Oyo state', Russian Journal of Agricultural and SocioEconomic Sciences 6(30), 3-8. https://doi.org/10.18551/rjoas.2014-06.01

Malkmus, G. \& Shockey, P., 2006, The hallelujah diet. Experience the ultimate health you were meant to have, Destiny Image Publishers, Shippensburg, PA.

Mbah, S.I, Mgbemena, G.C. \& Ejike, D.C., 2016, 'Urban poverty incidence in Nigeria: A study of Awka metropolis Anambra state of Nigeria', International Journal of Business and Social Science 7(5), 173-184.

McKenna, A., Augustyn, A., Bauer, P., Duignan, B., Eldrigde, A., Gregersen, E. et al., (eds.), n.d., 'Anambra', in Encyclopaedia Britannica, viewed 29 December 2019, from https://www.britannica.com/place/Anambra.

Merriam-Webster Dictionary, n.d., 'Child', in Merriam-Webster.com dictionary, viewed 17 February 2020, from https://www.merriam-webster.com/dictionary/child.

Nkwoka, A.O., 1983, 'St. Mark 10: 13-16 Jesus attitude to children: An exegetical and theological study', master's thesis, Department of Religion, Obafemi Awolowo University.

Nwafor, S., 2017, 'Anambra has the lowest poverty rate in Nigeria today - Obiano', Vanguard News, viewed 28 December 2019, from https://www.vanguardngr. com/2017/08/anambra-lowest-poverty-rate-nigeria-today-obiano/.

Nwamaka, O. \& Uzonwanne, M., 2017, 'Child labour and its determinants in informal sector of Onitsha, Anambra state, Nigeria', Research on Humanities and Social Sciences 7(20), 104-117. https://papers.ssrn.com/abstract=3199905.

Nwobi, A.U. \& Onwuasoanya, P.N., 2014, 'Rural women involvement in the eradication of poverty in Anambra state, Nigeria', Journal of Education and Practice 5(32), 104-110.

Nwogwugwu, U.C., Nwamaka, O, Nwokoye, E. \& Ezenekwe, R., 2017, 'Impact of child labour on human capital development in Onitsha, Anambra state, Nigeria', Journal of Education, Society and Behavioral Science 21(3), 1-12.

Nzeagwu, U., 2019, 'NGO awards scholarships to 35 indigent students in Anambra state', The Guardian, viewed 21 March 2019, from https://m.guardian.ng>news> nigeria.

Nzemeka, O., 2018, 'Anambra extends school feeding program to 16 new schools', The Guardian, viewed 29 December 2019, from https:/guardian.ng/news/anambragovernment-extends-school-feeding-programme-to-16-new-schools/.

Oganiru, A., n.d., History of Anambra state, viewed 29 December 2019, from http:// www.organiruanambra.org/about-oganiru-anambra/history-of-anambra-state/.

Okeke, I.M., Nnamani, D.O. \& Dibia, G.C., 2018, 'Inter-communal conflict and internally displaced persons in Nigeria : Analysis of Enugu and Anambra states, 2000-2007, Practicum Psychologia 8(1), 99-115.

Okeke, N., 2015, 'Poverty is driving a rise in the number of Nigerian child hawkers', in The Coversation, viewed 29 December 2019, from http://theconversation.com/ poverty-is-driving-a-rise-in-the-number-of-nigerian-child-hawkers- 49153.

Okeke, O.P., Imakwu, C.A., Eyo, J.E. \& Okafor, F.C., 2016, 'Prevalence of malaria infection in children in Anambra state, Nigeria after change of policy from presumptive/clinical to confirmed diagnosis', Animal Research International 13(1), 2385-2391. https://doi.org/10.9734/IJTDH/2016/26619

Okonkwor, U.C., 2012, 'About Anambra - Overview: Location \& people', in Anambra state of the Federal Republic of Nigeria, viewed 29 December 2019, from https:// anambra-state.blogspot.com/2012/05/about-anambra-overview-location-people. $\mathrm{html}$ ?m=0.

Olusegun, O.O. \& Idowu, A.A., 2016, 'Child abuse in Nigeria: Dimension, reasons for its persistence and probable', Child and Family Law Journal 4(1), 1-23. https:// lawpublications.barry.edu/cflj/vol4/iss1/2.
Onah, P., 2018, 'Obiano commends federal governments poverty intervention programme', in Anambra State Government webpage, viewed 29 December 2019 from http://lanambrastate Gove/nmens? poverty-intervention-programme\&hs=03a9ceed332d56a43de383bfc6468448.

Onyido, J.A. \& Vareba, G.P., 2019, 'Child abuse and its implications for sustainable development in Nigeria', International Journal for Innovation, Education and Research 7(2), 43-45. https://doi.org/10.31686/ijier.Vol7.Iss2.1320

Oxford Poverty and Human Development Initiative (OPHI), 2017, OPHI country briefing: Nigeria. Data for all, viewed 03 January 2020, from www.dataforall.org/ dashboardopiindex.

Oxford Poverty and Human Development Initiative (OPHI), 2018, 'Global multidimensional poverty index', in Oxford Poverty \& Human Development Initiative, viewed 26 December 2019, from https://ophi.org.uk/multidimensionalpoverty-index.

Owoaje, E.T., Ige, O.K. \& Bamgboye, E., 2011, 'Working school children in a Nigerian community: Revisiting the issues', International Journal of Health Research 4(1) 11-19. https://doi.org/10.4314/ijhr.v4i1.70430

Palmer, J., 2018, 'Poverty in the Old Testament - Lets talk about poverty', in Baptist Global Response, viewed 03 January 2020, from https://gobgr.org/poverty-in-theold-testament/.

Pamplona-Roger, G.D. (ed.), 2004, Encyclopedia of foods and their healing power A guide to food science and diet therapy, Review and Herald Publication Association, s.l.

Rufai, A.M., Yusuff, S.A, Awoyemi, T.T, Salman, K.K. \& Oyekale, A.S., 2016, 'Child poverty in rural Nigeria', Journal of Poverty, Investment and Developmemt 20 , 40-51. https://iiste.org>journalsJPID>article>view.

Ryan, T., 2014, 'How real food can help fight poverty', Talk Poverty, viewed 28 December 2019, from https://talkpoverty.org/2014/09/03/real-food-canhelp-fight-poverty/.

Smith, G., 2003, 'Poor, orphan, widow', in C. Brand (ed.), Holman illustrated Bible dictionary, p. 1312, Holman, Nashville TN.

Spender, R.D., 1996, 'Poor and poverty, theology of', in A.W. Elwell (ed.), Bakers evangelical dictionary of Biblical theology, Baker Books, Grand Rapids, MI.

Stewart, D. \& Okubo, T., 2017, A world free of child poverty: A guide to the tasks to achieve the vision, UNICEF, viewed 28 December 2019, from https://www.unicef. org>index_95280.

Strong, J., 1990, The new strongs exhaustive concordance of the Bible (comfort print edition), pp. 1099-1101, Thomas Nelson, Nashville, TN.

Ugochukwu, E., Okeke, K., Onubogu, C. \& Edokwe, E., 2012, 'Socio-demographic characteristics of child street vendors in Nnewi, Nigeria', Nigerian Journal of Paediatrics 39(4), 174-178. https://doi.org/10.4314/njp.v39i4.5

Ujumadu, V., 2016, 'Excitement as free feeding commences in Anambra schools', Vanguard Newspaper, viewed 29 December 2019, from https://www. vanguardngr.com/2016/11/excitement-free-feeding-commences-anambraschools/.

UNICEF, 2012, Save the children: The child development index - Holding governments to account for children's wellbeing, viewed 31 December 2019, from https:// unicef.org/socialpolicy/files/child-development-index.pdf.

UNICEF, 2015, Towards the end of child poverty: A joint statement by partners united in the fight against child poverty, viewed 03 January 2020, from https://www. unicef.org/socialpolicy/files/Towards_the_End_of_Child_Poverty_Joint Statement_by_Global_Partners_Oct2015. pdf.

UNICEF Nigeria, 2017, 'Children in Nigeria call for leaders to listen on World Children's Day', UNICEF Nigeria press release, viewed 29 December 2019, from https:// www.unicef.org/nigeria/press-releases/children-nigeria-call-leaders-listen-worldchildrens-day.

United Nations Development Programme \& Oxford Poverty and Human Development Initiative (UNDP \& OPHI), 2018, Half of world's poor are children, Human development report, viewed 03 January 2020, from http://hdr.undp.org/en/ content/half-worlds-poor-are-children.

World Bank, 2016, Poverty reduction in Nigeria in the last decade, Report No. NGA, Poverty Global Practice, Africa Region, World Bank, Washington, DC.

World Health Organization (WHO), 2016, Child maltreatment. Violence and injury prevention, viewed 03 January 2020, from https://www.who.int/news-room/factsheets/detail/child-maltreatment. 